\title{
Predictors of Acceptance of 'Lipa na Mpesa' Mobile Payment by Micro Entrepreneurs: A Case of Micro Entrepreneurs in Laikipia East Sub-county Kenya
}

\author{
Gatua Hosea Mwangi ${ }^{1}$, Bula Hannah Orwa ${ }^{2}$ \\ ${ }^{1}$ Entrepreneurship, School of Business, Kenyatta University, Nairobi City, Kenya \\ ${ }^{2}$ Human Resource Management, Entrepreneurship and General Management, Department of Business Administration, School of Business, \\ Kenyatta University Nairobi City, Kenya
}

\section{Email address:}

hosea.gatua@gmail.com (G. H. Mwangi), bula.oh@yahoo.com (B. H. Orwa), bula.hannah@ku.ac.ke (B. H. Orwa)

\section{To cite this article:}

Gatua Hosea Mwangi, Bula Hannah Orwa. Predictors of Acceptance of 'Lipa na Mpesa' Mobile Payment by Micro Entrepreneurs: A Case of Micro Entrepreneurs in Laikipia East Sub-county Kenya. Science Journal of Business and Management. Vol. 3, No. 6, 2015 , pp. $219-227$. doi: $10.11648 /$ j.sjbm.20150306.12

\begin{abstract}
Micro-entrepreneurs in the developing world are increasingly deploying the use of mobile payments to enhance the quality of their services and increase growth. The pace of transformation in the micro business sector has speeded up with more micro entrepreneurs realizing the potential of using mobile payments in their service delivery. This study aimed to examine the predictors of acceptance of 'Lipa na Mpesa' mobile payments by micro entrepreneurs in Laikipia East Sub County. The study sought to find out whether ease of use, perceived usefulness and attitude towards usage influence acceptance of 'Lipa na Mpesa' mobile payments by micro entrepreneurs in Laikipia East Sub County. The scope of the study was limited to micro entrepreneurs within Laikipia East Sub County. The study was carried out in Nanyuki town. Descriptive survey design was used for the study. The population of the study comprised of micro entrepreneurs signed up for Lipa Na Mpesa by Kopo Kopo Inc. within Nanyuki town. A sample of 124 micro entrepreneurs was selected for the study. The research methodology used was both quantitative and qualitative methods. Questionnaires comprised of structured and unstructured questions. Descriptive statistical analysis such as frequency counts and percentages were used. The correlation between the independent and dependent variables was determined by the use of regression analysis. Validity was ensured by checking whether the items in the questionnaire were reflected in the research questions and objectives of the study. Reliability of data collection instruments was ascertained through piloting the instruments. Data presentation was in bar graphs, pie charts and tables. The researcher also analyzed records and available documents in the learning institutions. The study established a high degree of variation $R^{2}=0.850(85.0 \%)$, that ease of use, perceived usefulness, attitude towards usage had on Intention to accept Lipa na Mpesa mobile payments. The researcher recommends that the service provider should maintain the technology deployed because it was found to be easy to use and also useful to micro entrepreneurs however, a further study is recommended to establish why most entrepreneurs had a low attitude towards using Lipa na M-pesa though they had signed up for the service initially.
\end{abstract}

Keywords: Lipa na M-pesa (Cell-Phone Type of Payment Using M-Pesa), Acceptance of Mobile Phone Payment, Micro Entrepreneurs, Mobile Commerce, Mobile Money

\section{Background of the Study}

The evolution of mobile devices and wireless technologies has brought about an exceptional effect in the world today, with the ability to communicate anywhere, at any place and at any time. Diniz (2011), stated that mobile technology can be viewed as a payment channel and has developed the possibility for two significant issues to be addressed at the same time; firstly is the demand side, which creates an opportunity for financial inclusion amongst the unbanked population and secondly the supply side which creates opportunities for financial institutions so they can deliver a wide range of services at minimum, mostly to people living in remote areas.

In a study by Aker and Mbiti (2010), they discussed that 
the proliferation of mobile devices has also brought about the introduction of a number of value added services, new technologies involving mobile transactions, while creating important commerce opportunities ranging from mobile banking to mobile payments (m-payments), and this was also supported by Must and Ludewig (2010). However, the different payment solutions that can be administered through the use of a mobile device are promising alternatives for countries that are still cash driven, and they are referred to as mobile payment services. The Gartner group (2009) defined mobile payment services as, paying for a product or service through the use of a mobile device and technology, including Near Field Communication (NFC), Short Messaging Services (SMS) and Wireless Application Protocol (WAP). Nevertheless, Dahlberg (2008) argued that mobile payments have brought about an exceptional increase in service opportunities for individuals, businesses, and a country's economy at large, especially in developing countries, which are currently implementing mobile payment services to aid financial inclusion.

Mobile commerce (M-Commerce) has become a relevant field when discussing mobile devices which allow users perform transactions any place and at any time (Knospe \& Grosche, 2004). The International Telecommunications Union, ITU (2011) estimated that by the end of 2011, there were over six billion mobile subscriptions which was equivalent to eighty-seven $(87 \%)$ percent of the world's population, and was a huge increase in contrast to the 5.4 billion recorded in 2010 and the 4.7 billion recorded in 2009 .

Mobile payments have never been more valued in any economy than it is today. According to the IFC (2011) report, mobile money involves the transfer of cash using mobile phones and is also an innovative method for both individuals and small businesses to transfer money. Hughes and Susie (2007) posits that a mobile money subscriber will be able to commence a financial transaction e.g. the transfer of money, send remittances, make payment for goods and services purchased, without the use of a physical depository which was supported by Mas and Morawczynski (2009). Mobile money service run on a telecommunications infrastructure centred on the Short Messaging Service (SMS) and the funds is conserved by the bank, while the subscribers' E-money balance either increases or decreases corresponding to usage (Ayo, 2011).

Mobile money operates without restrictions caused by time or distance, which has posed as a major issue in most developing countries, due to the distance and time it takes residents in rural areas to get to the bank (Must \& Ludewig, 2010). In addition, it has aided financial inclusion in developing countries by creating a scenario for the unbanked people to pay bills and transfer funds without using cash.

\section{Statement of the Problem}

Since the launch of M-pesa in March 2007 by Safaricom mobile operator, M-Pesa mobile payment has become popular with both the banked and the unbanked population serving as a deposit account for some(Mbogo, 2010).M-pesa was initially designed to perform $\mathrm{P} 2 \mathrm{P}$ payments but Entrepreneurs have further used it to accept $\mathrm{C} 2 \mathrm{~B}$ payments. The service enables subscribers to use their mobile phones to carry out transactions such as pay for goods and services, pay bills, send to and receive money from friends and family, withdraw cash for their use, top up their own airtime account or top up someone else's account and manage their own account. The use of mobile payment technology requires basic knowledge to operate. As a result, majority of the micro business operators in Kenya have embraced its use in their daily business operations and are registered users of M-Pesa. Consequently, they carry out various transactions using their mobile phones within and around their business surroundings such as paying suppliers for goods and services, paying bills, sending money to friends and relatives, withdrawing cash and topping up airtime accounts.

In July 2013 Safaricom Launched a product dubbed Lipa $\mathrm{Na}$ Mpesa to specifically address $\mathrm{C} 2 \mathrm{~B}$ payments and was meant to be a big boost for micro-entrepreneurs. However according to Kopo Kopo Inc. an American company contracted by Safaricom to sign up and manage entrepreneurs on Lipa na M-pesa payment system, they report that out of 12,500 entrepreneurs they have signed up, only about 3,000 are actively using the service (Wills, 2014). Zollmann (2014) concludes that until payments solutions solve real problems for the users themselves, we are unlikely to see wide scale usage of these payments mechanisms, and the benefits of mobile payments may not actually accrue to all players in the economy the way mobile payments evangelists hope. This posed a gap in understanding what would be used to predict effective usage of Lipa na M-pesa.

Several mobile payment trend studies have revealed the potential of mobile network technologies for payment purposes (Taga \& Karlson, 2004). Most of these studies were conducted in developed countries and thus may not reflect the predictors on acceptance of Lipa na M-pesa mobile payments by micro entrepreneurs in a developing country like Kenya. There existed a need therefore, for a substantive research to examine the predictors on acceptance of Lipa na Mpesa mobile payments by micro entrepreneurs in Kenya. So far there has been no clear insight into predictors on acceptance of Lipa na M-pesa mobile payments by micro entrepreneurs. This implies that technology providers, government agencies and development partners may not address the required interventions. It is for this reason that this research sought to examine the predictors on acceptance of Lipa na M-pesa mobile payment by micro entrepreneurs in Laikipia East Sub County. This was in quest to understand what can be used to predict acceptance of Lipa na M-pesa mobile payment by micro entrepreneurs in Laikipia East sub County.

\section{Theoretical Review}

Technology acceptance research is a continuous evolving field, as innovative technology evolves everyday (Al-Qeisi, 
2009), which has motivated information system researchers to develop a number of theoretical framework that attempts to predict the acceptance of a new technology. The technology acceptance model (TAM) which was proposed by David (1989), is one of such frameworks that has been used for predicting intentions to adopt new innovations. Ideally, a model that is useful not only for prediction but also explanatory is required by researchers, to enable them identify why a system is classified unacceptable, in order to develop corrective measures for that particular system to be acceptable. This research employed the use of TAM with additional constructs relating to mobile payments, to determine predictors on usage of M-pesa mobile payment by entrepreneurs in Nanyuki town.

\section{Technology Acceptance Model}

Technology Acceptance Model (TAM) is a theoretical model that explains how users come to accept and use a technology (Davis, 1989).TAM is widely adopted theory for examining the using of computers by the users. The theory was based on the Theory of Reasoned Action (TRA) by Ajzen and Fishbein (1980). TAM, first introduced by Davis (1989), it postulates that perceived usefulness and perceived ease of use as major determinants for using computers. Perceived usefulness is defined as the degree to which a person believes that using a particular system would enhance his/her job performance, while perceived ease of use refers to the degree to which a person believes that using a particular system would be free of effort (Davis, 1989). These two beliefs determine the majority of variance in adoption of a new technology.

Consequently, the theory was further evaluated by subsequent studies. For instance, Davis (1989) conducted a comparison study between TAM model and theory of reasoned action (TRA). Davis (1989) found perceived usefulness to be strong predictor of behavioral intention to use the system, whereas perceived ease of use had also effect on intention. Attitude towards using the systems was found to be partially mediating the prediction of these two variables on the outcome (intention). In addition, their study suggested that intention predicts computer usage. The TAM model is considered the most popular theory examining the determinants of information systems among the researchers (Luarn \& Lin, 2005). Although previous studies widely adopted this theory, many constructs were added to the original model. As noted by Davis (1989), TAM model may not fully predict all the variances in the user adoption. This means that there are other variables that may influence the user acceptance. As such, several constructs were incorporated to the original model including perceived credibility, perceived self-efficacy, and perceived financial cost (Laurn \& Lin, 2005); technology-specific valuation, and number of users, among others (Wang, Lo, \& Fang, 2008).

Much literature relating to the information systems usage has dropped the attitude contrast from the original TAM model. For example, Venkatesh and Davis (1996) used the
TAM model without attitude. They argued that this construct did not mediate the effect of beliefs about the system on the actual usage. This also was observed in other similar studies (Ramayah \& Ignatuis, 2005; Luarn \& Lin, 2005; Wang et.al, 2008). The current study omits actual usage due to exploratory nature of the study and the study's intention to explore only the entrepreneurs' intention to adopt the service.

\section{Ease of Use}

Rogers (1983) stated that perceived ease of use is the degree to which an innovation is perceived not to be difficult to understand, learn or operate and to which users perceive a new product or service as better than its substitutes. According to Kim (2008) perceived ease of use has a direct effect on perceived usefulness and has a positive relationship on user's adoption; in addition perceived ease of use has a direct impact on perceived usefulness and impacts user adoption directly and indirectly.

Davis (1989) stated that, Perceived Usefulness (PU) can be described as "the measure by which a person believes that using a particular system would enhance his or her job performance", while Perceived Ease of Use (PEOU) is defined as, "the degree to which a person believes that using a particular system would be free of effort" (Davis, 1989). Davis et al. (1989) further stated that PU and PEOU can influence one's attitude towards using a particular system, which also influences the intention to use the system and in turn decides actual system usage. Several studies have also stated the necessity of perceived usefulness and perceived ease of use for mobile payment acceptance (Dahlberg et al., 2003; Dahlberg et al., 2002; Pousttchi, 2003), and the fundamental reason is that IT users react rationally when they decide to use IT. In addition Jeyaraj et al. (2006), in reviewing technology adoption studies, discovered that among 29 studies carried out from 1992-2003, perceived usefulness is seen to be significant in 26 of the studies. In addition, perceived usefulness is a general construct, functional in previous mobile commerce and mobile payment literatures. Wei et al. (2009) in their study of mobile commerce in Malaysia found perceived usefulness to be positively associated with consumer's intention to use mobile commerce in Malaysia.

Nevertheless, like PU, PEOU was adapted from TAM, even though consumers consider the system useful, they could still think it is difficult to use (Davis, 1989). In addition, apart from perceived usefulness, perceived ease of use can likewise be said to be a key significant factor in the acceptance of a number of information technologies, e.g. the intranet (Chang, 2004), electronic banking (Wang et al., 2003) and wireless internet (Shih \& Fang, 2004).Similarly, Amin (2007) in his study established the significance of perceived ease of use as a decisive factor, which influences a consumer's intention to use mobile credit card transactions. However, despite of the fact that a number of studies have found perceived ease of use a significant factor, some others do not, for example Pikkarainen et al., (2004) and Wei et al., 
(2009) established that perceived ease of use does not have a significant effect on consumers' intention to use.

The perceived ease of use and usefulness of a mobile payment procedure therefore has an effect on its usage, and Davis (1989) opines that perceived ease of use of a system has a direct influence on perceived usefulness which was reflected in the proposed model.

\section{Perceived Usefulness}

Perceived usefulness is said to be the degree to which an individual thinks that using a particular system will enhance his/her work efficiency (Davis, 1989). This implies that the potential advantages of using mobile money services such as convenience, transactions efficiency, affordability, easy accessibility, security, and safety over the existing financial systems influence an individual's behavioural intention to adopt the service (Tobbin, 2011). Further, empirical evidence indicates that the mobility of mobile money services, the presence of facilitating conditions such as government and technical support, and the system quality as indicated by network coverage, reliability and stability are also determinants of perceived usefulness that have a direct effect on behavioural intention of use and eventual adoption of the service (Schierz et al., 2010).

\section{Attitude towards Usage}

Attitude towards usage (ATU) refers to the degree to which an individual evaluates and associates the target

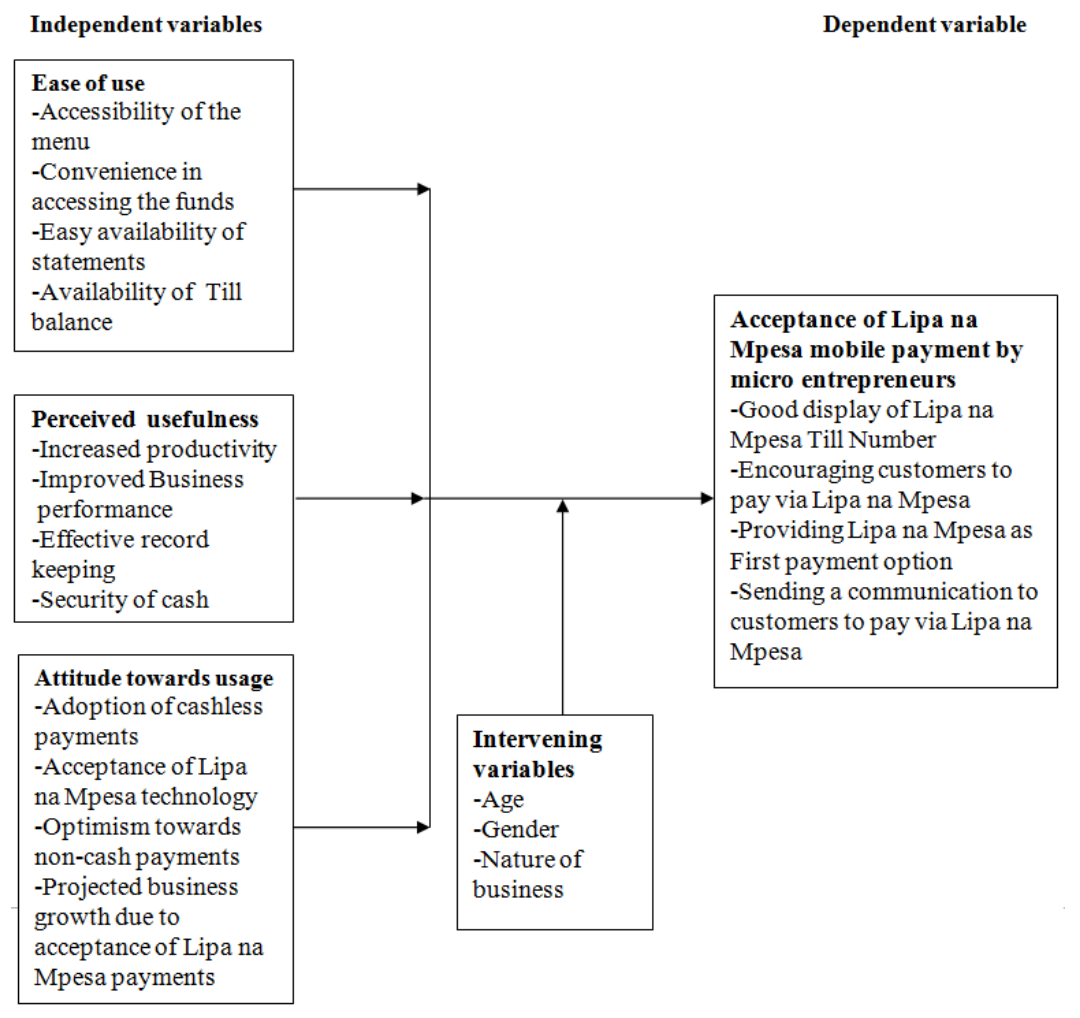

Source: Author (2015) system with his or her job (Davis, 1993). Attitude towards usage has been identified as a factor that guides future behaviour or the cause of intention that ultimately leads to a particular behaviour. In TAM, attitude towards usage is referred to as the evaluative effect of positive or negative feeling of individuals in performing a particular behaviour (Ajzen \& Fishbein, 2000). Attitude towards usage (ATU) leads to personal Innovativeness which is defined as the willingness of an individual to try out any new information systems. Consumer innovativeness is positively related to their adoption decision of various technologies. Innovative individuals have been also found to be dynamic, communicative, curious, venturesome, and stimulationseeking. Other diffusion studies also confirmed that innovativeness is related to consumer adoption behaviour.

According to Rogers' theory of the diffusion of innovations, Agarwal and Prasad (1998) described personal innovativeness as symbolizing the risk taking propensity that exists in certain individuals and not in others. They are able to cope with high levels of uncertainty and develop more positive intensions toward acceptance (Rogers, 2003). In the intention to adopt, most people do not have any or much knowledge on various mobile services or form clear perception beliefs. It is expected that personal innovativeness generating a strong impact on perceived usefulness and perceived ease of use, which in turn influence user intention to adopt technology.

\section{Conceptual Framework}

Figure 1. Predictors on acceptance of Lipa na Mpesa mobile payments by micro entrepreneurs in Laikipia East Sub county. 


\section{Research Methodology}

The study envisaged examining the predictors on acceptance of Lipa na Mpesa mobile payment by micro entrepreneurs in Laikipia East Sub County. To do this, the researcher employed a descriptive research design. This type of research design entails making observation or collecting data of the research subject and describing the behaviour of the subject without influencing it in any way. It relied heavily on questionnaires to collect the primary data while secondary data was collected from journals, newspapers and other reliable sources containing information on the subject of the study (Elahi \& Dehdashti, 2011).Considering the main purpose of the study was to determine the predictors on acceptance of Lipa na Mpesa mobile payment by micro entrepreneurs in Laikipia East Sub County, it was most appropriate that the target population to be composed of micro entrepreneurs who had signed up for Lipa na M-pesa mobile payment technology. The study therefore targeted 310 micro entrepreneurs in Laikipia East Sub-county who had been signed up for Lipa na M-pesa by Kopo Kopo Inc.

Systematic random sampling was used to select micro entrepreneurs signed by Kopo Kopo Inc. for Lipa na M-pesa mobile payment who participated in the study. They formed the main respondents. A sample size of $40 \%$ was used. According to Gay (1976), for a descriptive research, a sample size of $40 \%$ of the accessible population is considered representative.

Table 1. Sampling Frame.

\begin{tabular}{llll}
\hline & $\begin{array}{l}\text { Total } \\
\text { population }\end{array}$ & Sample size & Percentage (\%) \\
\hline $\begin{array}{l}\text { Active Micro } \\
\text { entrepreneurs }\end{array}$ & 93 & 37 & 40 \\
$\begin{array}{l}\text { Inactive Micro } \\
\text { entrepreneurs }\end{array}$ & 217 & 87 & 40 \\
Total & 310 & 124 & 40 \\
\hline
\end{tabular}

Source: Kopo Kopo Inc., 2015

\section{Data Analysis}

The sample comprised of 124 respondents. The returned questionnaires were 110 representing $88.7 \%$ response rate. This response rate was adequate and representative and conforms to Mugenda and Mugenda (1999) stipulation that a response rate of $50 \%$ is adequate for analysis and reporting; a rate of $60 \%$ is good and a response rate of $70 \%$ and over is excellent. The response rate was due to the fact that the sample population was well educated and knew the importance of research studies. In addition the questionnaire were presented to the respondents and collected at the agreed time and date. This gave them adequate time to adequately and fully complete them.

\section{Demographic Characteristics}

Table 2. Demographic Characteristics.

\begin{tabular}{|c|c|c|}
\hline \multicolumn{3}{|l|}{ Gender } \\
\hline & $\mathrm{f}$ & $\%$ \\
\hline Male & 49 & 44.5 \\
\hline Female & 61 & 55.5 \\
\hline \multicolumn{3}{|l|}{ Age bracket (Yrs) } \\
\hline & $\mathrm{f}$ & $\%$ \\
\hline Below 20 & 2 & 1.8 \\
\hline $20-30$ & 37 & 33.6 \\
\hline Above 30 & 71 & 64.6 \\
\hline \multicolumn{3}{|c|}{ Owner/ Not owner } \\
\hline & $\mathrm{f}$ & $\%$ \\
\hline Yes & 87 & 79.1 \\
\hline No & 23 & 20.9 \\
\hline \multicolumn{3}{|c|}{ Highest level of education } \\
\hline & $\mathrm{f}$ & $\%$ \\
\hline Primary & 5 & 4.5 \\
\hline Secondary & 76 & 69.1 \\
\hline Tertiary/College & 21 & 19.1 \\
\hline University & 8 & 7.3 \\
\hline \multicolumn{3}{|l|}{ Business type } \\
\hline & $\mathrm{f}$ & $\%$ \\
\hline Whole sale & 5 & 4.1 \\
\hline Retail & 65 & 52.8 \\
\hline Manufacturing & 7 & 5.7 \\
\hline Service & 43 & 35 \\
\hline Other (specify) & 3 & 2.4 \\
\hline
\end{tabular}

Majority, $61(55.5 \%)$ of the respondents were female while $49(44.5 \%)$ were males. This shows the businesses had a good representation meeting the constitutional gender distribution threshold of 30\% (constitution of Kenya, 2010). $71(64.6 .3 \%)$ of the respondents were 30 years and above, followed by 37 (33.6\%) aged between $20-30$ years while only $2(1.8 \%)$ of the respondents were below 20 years. This shows that the majority of the micro entrepreneurs were in their productive years. This implies that they were able to work and manage their businesses efficiently. On business ownership, $87(79.1 \%)$ of the respondents owned the businesses while only $23(20.9 \%)$ did not. This show that majority of the businesses operated as sole proprietorship enterprises.

Level of education indicated that 76 (69.1\%) of the respondents had secondary education followed by tertiary/college education 21(19.1\%) next 8 (7.3\%) had university degrees while only $5(4.5 \%)$ had primary education. On sector of operation, $65(59.1 \%)$ were in retail sector, 29 (26.4\%) service sector, 8(7.3\%) in manufacturing, $5(4.5 \%)$ in whole sale sector while $3(2.7 \%)$ had closed their businesses though they had signed up for Lipa na M-pesa till numbers. 


\section{Regression Analysis}

Table 3. Model Summary.

\begin{tabular}{lccll}
\hline Model & R & R Square & $\begin{array}{l}\text { Adjusted R } \\
\text { Square }\end{array}$ & $\begin{array}{l}\text { Std. Error of the } \\
\text { Estimate }\end{array}$ \\
\hline 1 & $.922^{\mathrm{a}}$ & .850 & .846 & .40715 \\
a. & Predictors: (Constant), Attitude & towards usage, & $\begin{array}{l}\text { Perceived usefulness, } \\
\text { Ease of use }\end{array}$ \\
\hline
\end{tabular}

The study established a high degree of variation $R^{2}=0.850$ $(85.0 \%)$, that Ease of use, perceived usefulness, attitude towards usage had on Intention to accept Lipa na M-pesa mobile payments. This indicated that intention to use mobile payments could be predicted by the constructs of Ease of use, perceived usefulness and attitude towards usage. The findings confirm that in order to predict how well a given mobile payment technology would be adopted by targeted users, users' perception on ease of use, usefulness and attitude towards the technology would be good predictors. The study agreed with Bhatti (2007) study which established that perceived usefulness, perceived ease of use, subjective norms, behavioural control and personal innovativeness contribute significantly $(\mathrm{F}=15.21 ; \mathrm{p}<.001)$ and predict $68 \%$ of variations in user's intention.

Table 4. ANOVA ${ }^{a}$.

\begin{tabular}{|c|c|c|c|c|c|c|}
\hline Model & & $\begin{array}{l}\text { Sum of } \\
\text { Squares }\end{array}$ & df & $\begin{array}{l}\text { Mean } \\
\text { Square }\end{array}$ & $\mathbf{F}$ & Sig. \\
\hline \multirow{3}{*}{1} & $\begin{array}{l}\text { Regressi } \\
\text { on }\end{array}$ & 99.846 & 3 & 33.282 & \multirow[t]{3}{*}{$\begin{array}{l}200.7 \\
72\end{array}$} & \multirow[t]{3}{*}{$.000^{\mathrm{b}}$} \\
\hline & Residual & 17.572 & 106 & \multirow[t]{2}{*}{.166} & & \\
\hline & Total & 117.418 & 109 & & & \\
\hline \multicolumn{7}{|c|}{$\begin{array}{l}\text { a. Dependent Variable: Intention to accept Lipa na Mpesa payments } \\
\text { b. Predictors: (Constant), Attitude towards usage, Perceived usefulness, } \\
\text { Ease of use }\end{array}$} \\
\hline
\end{tabular}

Table 4 on analysis of variance has a significant $F=200.772$ indicating that using the model is better than guessing the mean. The significant value 0.000 is less than $\alpha$ $=0.05$ which means there is no significant difference between the means of the constructs. This implies that a slight change in one variable highly affects the acceptance of Lipa na M-pesa mobile payments. These analyses further confirm that the model is a good fit for the study.

Table 5. Coefficients ${ }^{a}$.

\begin{tabular}{|c|c|c|c|c|c|c|}
\hline \multirow{2}{*}{ Model } & & \multicolumn{2}{|c|}{ Unstandardized Coefficients } & \multirow{2}{*}{$\begin{array}{l}\text { Standardized Coefficients } \\
\text { Beta }\end{array}$} & \multirow{2}{*}{$\mathbf{t}$} & \multirow{2}{*}{ Sig. } \\
\hline & & B & Std. Error & & & \\
\hline \multirow{4}{*}{1} & (Constant) & -.909 & .290 & & -3.128 & .002 \\
\hline & Ease of use & .403 & .078 & .445 & 5.184 & .000 \\
\hline & Perceived usefulness & .588 & .094 & .425 & 6.247 & .000 \\
\hline & Attitude towards usage & .170 & .130 & .104 & 1.306 & .194 \\
\hline
\end{tabular}

The absolute standardized coefficient for Ease of use $B e t a=0.445$ and perceived usefulness Beta $=0.425$ indicates a significantly influence on entrepreneurs' intention to accept Lipa na Mpesa mobile payments. This implies that the respondents perceive Lipa na Mpesa easy to use, they also perceive Lipa na Mpesa to be useful in running their business. This was in agreement with Mbogo (2010) findings which indicated that Perceived ease of accessibility (Ease of use) had an impact on the intention to use the mobile payment services. The findings however disagree with the findings of Nykvist and Stalfors (2011) which established a low significant level relationship between Subjective Norm and perceived ease of use on behaviour intention to use mobile payment services.

Attitude towards usage has a low absolute standardized coefficient at Beta $=0.104$ which meant that Entrepreneurs' attitude towards using Lipa na M-pesa had low contribution on intention to accept Lipa na M-pesa mobile payments. This is further supported by a low confidence level of $80.6 \%$ (100\%-19.4\%) on Attitude towards usage that was far much below the research thresh hold of at least $95 \%$ level of confidence. This means that even though most entrepreneurs signed up for Lipa na Mpesa, some later developed a negative attitude towards using it and hence have a low intention of using Lipa na M-pesa.

The correlation between the dependent variables i.e. intention to accept Lipa na M-pesa mobile payments and independent variables i.e. ease of use, perceived usefulness and attitude towards usage was established using the regression model as below:

$$
Y=-0.909+0.403 X_{1}+0.588 X_{2}+0.170 X_{3}+\varepsilon
$$

Where $\mathrm{Y}=$ intention to accept Lipa na Mpesa mobile payments (dependent variable)

$\mathrm{X}_{1}=$ ease of use

$\mathrm{X}_{2}=$ perceived usefulness

$\mathrm{X}_{3}=$ attitude towards usage

$\varepsilon=$ Error

\section{Summary of the Findings}

The study sought to examine the predictors on acceptance of Lipa na M-pesa mobile payment by micro entrepreneurs in Laikipia East sub County. It was further guided by three specific objectives whose findings are outlined below:

\section{Ease of Use Influence on Acceptance of Lipa na Mpesa Mobile Payment}

Majority of the respondents $90.9 \%$ are able to pay through Lipa na M-pesa with $50 \%$ agreeing while $40.9 \%$ strongly agreeing. On calculating fee charged on Lipa na M-pesa $72.7 \%$ agreed it was easy with $9.1 \%$ strongly agreeing. The 
study found out that $66.3 \%$ and $9.1 \%$ of the respondents strongly agree and agree respectively that accessing Lipa na M-pesa menu on their phone was easy. This indicates that the technology deployed provides an easy way of making payments and also calculating the transaction fees.

The study found out $54.5 \%$ of the respondents disagreed while $19.1 \%$ strongly disagree that accessing their money from Lipa na M-pesa was easy. This means that mobile payments technology need to provide an easy way of accessing the funds once received via the mobile till. Another $50 \%$ of the respondents disagreed that checking Lipa na

M-pesa till balance is easy raising the need for technology providers to provide a solution on an easy way to check balance of funds in the Mobile till.

\section{Perceived Usefulness Influence on Acceptance of Lipa na Mpesa Mobile Payment}

The findings showed that a total of $90 \%$ respondents representing $83.6 \%$ of the respondents who agreed and $6.4 \%$ strongly agreed that their money was secure when paid through Lipa na M-pesa than when paid through cash. This is an indication that mobile payment technology provided security of cash. However $60.9 \%$ and $64.5 \%$ were not sure whether Lipa na M-pesa reduced the number of times they visited the bank and the impact of Lipa na Mpesa had on business profitability respectively. There was also $66.3 \%$ of the respondents who were not sure whether using Lipa na M-pesa increases productivity in their businesses by them being able to serve more customers. These three aspects highlighted the need for technology providers to educate the end user on the usefulness and added values associated with mobile payments.

On the impact of Lipa na M-pesa to business performance $50 \%$ of the respondents disagreed that it had any impact while $40.9 \%$ were not sure, this and indicator that micro entrepreneurs lack the insight on how mobile payments can improve business performance. Though perceived usefulness has a high influence on intention to use Lipa na M-pesa. The influences on the respondents seem to be negative and thus could be a contributing factor to the low activity of signed up tills.

\section{Attitude Towards Usage Influence on Acceptance of Lipa na M-pesa Mobile Payment}

The study showed that majority of the respondents $77.3 \%$ agree they would like to receive more non-cash payments in their business while $79.1 \%$ agreed that accepting Lipa na M-pesa mobile payment would help their business grow. These findings are an indicator that micro entrepreneurs had a positive attitude towards using mobile payments. These analogy were further supported by $89 \%$ of the respondents representing $82.7 \%$ and $6.3 \%$ of the respondents who agreed and strongly agreeing respectively that receiving more Lipa na Mpesa payments is better than cash.

However only $24.5 \%$ agreed that many businesses would use Lipa na $M=$ pesa in future with a significant number of respondents $(70 \%)$ being not sure. This calls for a quick address of the factors mentioned in the other constructs in order to guarantee future use of mobile payments. The encouraging aspect is that $63.7 \%$ of respondents agreed that it is hard to operate a business without accepting mobile payments which means there is a bright future in the mobile payments space.

\section{Conclusions}

The research findings indicate that intention to use Lipa na M-pesa mobile payments is highly influenced by ease of use and perceived usefulness and slightly by attitude towards usage. The ease of use factors that were found to have a positive influence included ability to pay through Lipa na Mpesa, calculating fee charged on Lipa na Mpesa and accessing Lipa na M-pesa menu on the phone were easy. While accessibility of money from Lipa na Mpesa till and checking Lipa na M-pesa till balance were found to be wanting and thus need to improve the technology deployed on to these processes.

Micro entrepreneurs perceived there money to be secured when paid through Lipa na M-pesa thus the service provider should use this as a value preposition when marketing the product. It was not clear on how Lipa na M-pesa improved business productivity and profitability, more user education could help to clearly bring out this value preposition. Majority of the micro entrepreneurs agree they would like to receive more non-cash payments in their business and also believe that accepting Lipa na M-pesa mobile payment would help their business grow. This creates a big market for mobile payments service providers to tap into because micro entrepreneurs admit that it is hard to carry out business without accepting mobile payments

\section{References}

[1] Ajzen, I., \& Fishbein, M. (2000). Attitudes and the attitudebehaviour relation: Reasoned and automatic processes, in Stroebe, W. and Hewstone, M. (eds.), European review of social psychology. John Wiley \& Sons, pp. 1-33.

[2] Aker, J., \& Mbiti, I. (2010). Mobile Phones and Economic Development in Africa, Journal of Economic Perspectives, 24(3), pp. $207 \quad-\quad 232$. Available at: http://www.cgdev.org/files/1424175_file_Aker_Mobile_wp21 1_FINAL.pdf (Acessed: 25 January $\overline{2015}$ ).

[3] Anurag, S., Tyagi, R. \& Raddi, S. (2009). Mobile Payment 2.0: The Next-Generation Model, in HSBC's Guide to cash, Supply Chain and Treasury Management in Asia Pacific.Ed.178-183.

[4] Arunga, J., \& Kahora, B. (2007). Cell phone Revolution in Kenya. International Policy Network. 
[5] Au, Y.A., \& Kauffman, R.J. (2008) 'The economics of mobile payments: Understanding stakeholder issues of an emerging financial technology application', Journal of electronic commerce research and applications, 7(1), pp.141-164.

[6] Ayo, C. (2011). Framework for mobile money Implementation in Nigeria, Journal of African Research in Business and Technology 2011 (2011) [Online].Available at: http://www.ibimapublishing.com/journals/JARBT/2011/11786 0/117860.pdf (Accessed: 24 January 2015).

[7] Bryman, A., \& Burgess, R. (2003). Analysing qualitative data, Taylor \& Francis e-library.

[8] Business Daily. (2009). "M-pesa success stirs bank fury as 5 million subscribers enrol" Business Daily. January 12, 2009. $<$ http://www.bdafrica.com> accessed on 18th March, 2015.

[9] Business Daily. (2009). Minister orders audit of Safaricom MPesa service. Business Daily, April 18, 2009. http://www.bdafrica.com Accessed on 18th January, 2015.

[10] Communications Commission of Kenya, (2008). Communications Statistics Report Second Quarter. <http: //www.cck.go.ke.> Accessed on 28th January, 2015.

[11] Cresswell, J. (2003). Research design: qualitative and quantitative approaches. London: Sage.

[12] Dahlberg, T. (2008). Consumer acceptance of mobile payment solutions - ease of use, usefulness and trust. In Proceedings of the Second International Conference on Mobile Business (ICMB), Vienna, Austria, 23 - 24, June.

[13] Davis, F. (1989). 'User acceptance of computer technology: A comparison of two theoretical model', Management Science, 35(8), pp. 982-1003.

[14] Diniz, E. (2011a). Mobile Money and Payment; a literature review based on academic and practitioner-oriented publications 'In Proceedings of SIG Global Development Annual Workshop. Shangai, 3 December. China Available at:http:/www.globdev.org/files/Shanghai\%20Proceedings/24 \%20REVISED\%20Diniz\%20Mobile_Money_and_Payment Nov\%2014\%202011.pdf (Accessed: 25 March 2015).

[15] Diniz, E. (2011b). 'Triggers and barriers to financial inclusion: The use of ICT- based branchless banking in an Amazon county', Electronic Commerce Research and Applications, Science Direct [Online]. Available at: http://ac.elscdn.com/S1567422311000433/1-s2.0-

S1567422311000433-main.pdf?_tid=f51f0f6a-f2e6-11e1$81 \mathrm{c} 7-$

00000aab0f6b\&acdnat=1346361136_7eb52057c0a868b9abd6 71 ea881785f1 (Accessed; 25 March 2015).

[16] Elahi, M., \& Dehdashti, M. (2011). Classification of researches and evolving a consolidating typology of management studies, annual conference on innovations in business \& management, London, UK.

[17] Elder, L., \& Rashid, A.T. (2009) Mobile Phones and Development: An analysis of IDRC-Supported Projects. The Electronic Journal on Information Systems in Developing Countries 36, 2, <http: //www.ejisdc.org.> Accessed on 28th March, 2015.

[18] Gall, N., Gall, P. Joyce, D., \& Walter, R. (1996). Education Research: An introduction: New York Longman Publishers.

[19] Gartner Group. (2009). Mobile Payment, 2007 - 2012.
[20] Government of Kenya, (1999). National Medium and Small Enterprises Baseline Survey, Kenya National Bureau of Statistics. <http://www.knbs.go.ke.> Accessed 28th March, 2015.

[21] Hughes, N., \& Lonie, S. (2007). M- PESA: Mobile Money for the "Unbanked"; Turning Cell phones into 24-Hour Tellers in Kenya. Available

at: http://www.policyinnovations.org/ideas/policy library/data/m pesa/_res/id=sa_File1/INNOV0201_pp-63-81_hugheslonie_1.pdf (Accessed: 23rd March 2015).

[22] Innopay. (2010). Mobile Payments 2010; Market Analysis and Overview Available at:https://www.nacha.org/userfiles/File/The_Internet_Council/ Resources/Mobile\%20payments\%202010\%20\%20Innopay.pdf (Accessed: 4th February 2015).

[23] Juniper Research. (2008). Mobile payment markets digital \& physical goods, Juniper Research.

[24] Kadhiwal, S., \& Zulfiquar, M. (2007) Analysis of mobile payment security standards and different measures, Computer Fraud and Security 2007(6), pp. 12-16. Science Direct [Online], Available at: http://www.sciencedirect.com/science/article/pii/S1361372307 700775 (Accessed: 29 January 2015).

[25] Knospe, H., \& Grosche, S. (2004). Secure mobile Commerce in Mitchell, C. (ed.) Security for mobility. London: The Institution of Electrical Engineers, pp. 326-346.

[26] Lim, E., \& Siau, K. (2003). Advances in Mobile Commerce Technologies London: Idea Group Publishing.

[27] Luarn, P., \& Lin, H. (2005). Toward an Understanding of The Behavioural Intention to Use Mobile Banking, Computers in Human Behaviour, 21(1), pp.873-891.

[28] Mahatanankoon, P. (2005) 'Consumer -based m-commerce: Exploring consumer perception of mobile applications', Computer Standards and Interfaces, 27(4), pp.347-357.

[29] Mallat, N. (2007). Exploring consumer adoption of mobile payments, A qualitative study Journal of Strategic Information Systems, 16(1), pp. 413-432.

[30] Mas, I., \& Morawczynski, O. (2009). 'Designing Mobile Money services', Lessons from M-PESA, 4(1), pp. 77-91.

[31] Mbogo, M. (2010).The Impact of Mobile Payments on the Success and Growth of Micro-Business: The Case of M-Pesa in Kenya.

[32] Morawczynski, O. (2008). 'Surviving in the dual system': How $M$-PESA is fostering urban-to-rural remittances in Kenyan Slume ${ }^{e}$ Available at: http://www.mobileactive.org/files/file_uploads/Olga_Morawc zynski-M-PESA-2008.pdf (Accessed: February 4, 2015).

[33] Mugenda, O., \& Mugenda, A. (2003). Research methods: Qualitative approaches. Publishers Act Press, Nairobi.

[34] Must, B., \& Ludewig, K. (2010). 'Mobile Money: Cell Phone Banking in developing Countries', Policy Matters Journal, pp. 27-33.

[35] Nachimas, C.F., \& Nachimas, D. (1999). Research methods in Social Science. Arnold publication. London.

[36] Ondrus, J., \& Pigneur, Y. (2006) 'Towards A Holistic Analysis of Mobile Payments: A Multiple Perspectives', Electronic Commerce Research and Applications. 5(3), pp.246-257. 
[37] Orodho, A. J. (2003). Essentials of educational and social sciences research methods. Masola Publishers.

[38] Orodho, J.A. (2008). Techniques of writing research proposals and reports in Education and social sciences. Kanezja Hp Enterprises.

[39] Ott, L., \& Longnecker, M. (2008). An introduction to statistical methods and data analysis. Cengage Learning, New York.

[40] Porteous, D. (2006). The enabling environment for mobile banking in Africa. London: DFID.

[41] Ramayah \& Ignatius (2005). Impact of Perceived usefulness, Perceived ease of use and Perceived Enjoyment on Intention to shop online, ICFAI Journal of Systems Management (IJSM) [Online] Available http://ramayah.com/journalarticlespdf/impactpeu.pdf (Accessed: 29th January 2015).

[42] Smith, M. (2010). Analysis of roles and position of mobile network operators in mobile payment infrastructure, In $21 \mathrm{st}$ European Regional ITS Conference, Copenhagen. Available at: http://hdl.handle.net/10419/44311 (Accessed: 28th January 2015).
[43] Taga, K., \& Karlsson, J. (2004). little Global M-Payment Report, Vienna, Austria.

[44] Venkatesh, V., \& Davis, F. D. (1996) 'A model of the antecedents of perceived ease of use: Development and test', Decision Sciences, 27(3), 451-481.

[45] Wang, Y., Wang, Y., Lin, H., \& Tang, T. (2003) 'Determinants of user acceptance of internet banking: An empirical study', International Journal of Service Industry Management, 14(5), pp. 501-519.

[46] Wills, A. (2014). Global System for Mobile communication. Intelligence Mobile for Development. London.

[47] Young, R., \& Jordan, E. (2008). Top management support: Mantra or necessity? Int J Project Manage.

[48] Zollmann, J. (2014). Digital Retail Payments in Kenya: Making them Matter for Merchants. BFA, LLC, 48 Grove Street, Suite 106, Somerville, MA 02144 USA. 